\title{
MARKETING AND UTILIZATION OF MORINGA SEEDS (MORINGA OLEIFERA LAMK) AS WELL WATER PURIFIERS IN PADANG BULAN SELAYANG DISTRICT 2.
}

\author{
Nurul Fajriah ${ }^{1)}$, Sudarmi ${ }^{2)}$, Julia Reveny ${ }^{3)}$ \\ ${ }^{1)}$ Faculty of Agriculture, University of North Sumatra \\ Email: nurulfajriahpinem@usu.ac.id \\ ${ }^{2)}$ Faculty of Pharmacy, University of North Sumatra \\ Email: Sudarmi.Sastrowirono@gmail.com \\ ${ }^{3)}$ Faculty of Pharmacy, University of North Sumatra \\ Email: juli_r2005@yahoo.com
}

\begin{abstract}
This service activity was carried out in Padang Bulan Selayang 2 Village, North Sumatra Province. This activity aims to help clear the water from the local dug wells because there are still many dangerous bacteria and metals found in the well water content. To purify well water, it is done by using powdered Moringa oleifera seeds which are put into well water before consumption and Moringa seeds will absorb harmful metals and bacteria contained in the well water content. This service also helps residents of Padang Bulan Selayang 2 Village to be able to make their own Moringa seed powder with tools and materials that are available so that they can meet their daily needs. Marketing can be done from house to house or through an online system by introducing to the general public the benefits of Moringa seeds as well water purifiers.
\end{abstract}

\section{INTRODUCTION}

Dug well water is part of ground water which has some disadvantages or weaknesses compared to other water sources, because it contains mineral substances and high concentrations. These minerals include magnesium, calcium and iron which cause hardness (Munfiah, et al., 2013).

One of the ingredients for water purification is moringa fruit which is widely found in rural and urban areas which are usually used as hedgerows, land boundaries and medicines. Moringa fruit used in this study is Moringa fruit that is ripe or old, the old Moringa fruit is brownish in color, while the Moringa fruit is still green (Kharistya, 2006).
Moringa seeds are part of Moringa plants that have high concentrations of protein. Moringa seed protein is important to know in the process of purifying water, this protein acts as a coagulant of particles that cause turbidity. Moringa seeds also act as an effective coagulant because of the active 4-alfa-4-rhamnosyloxy-benzilisothiocynate active ingredient contained in Moringa seeds (Khasanah, 2008).

The population around Padang Bulan Selayang 2 Village, on average, still has a middle to lower level of living. So that there are still many people who use dug well water for daily consumption. While the content in excavated well water still contains many bacteria and metals that are harmful to health if consumed for a long time.

To overcome this problem can be done by reducing the metal concentration in the waters with the absorption method. The 
Nurul.et.al. Marketing And Utilization Of Moringa Seeds (Moringa Oleifera Lamk) As Well Water Purifiers In Padang Bulan Selayang District 2.

absorptive method is able to collect dissolved substances in the solution using absorbent substances or compounds. One of the natural absorbent ingredients that can be used is as much as Moringa oleifera Lamk. (Umar and Liong, 2014).

\section{METHOD}

Retrieval of dug well water Retrieval of well water dug on Jl. Lotus Flower Market 2 Padang Bulan, Medan. With the criteria for well water taken are: a. The location of the well is close to the source of contamination (MCK is less than $10 \mathrm{~m}$ ). b. Wells are used in various activities of the surrounding community. c. Does not meet physical requirements (colored and smelling). $d$. Does not meet construction requirements (does not have sewerage). Taken water using sterilized glass bottles (Latif, 2014)

\subsection{Making Moringa Seed Simplicia}

The old Moringa fruit is brown and looks dry harvested. After that, the seeds are weighed and then removed and the seeds and epidermis are removed so that the seeds are clean. The seeds are dried in a drying cabinet using 40 watts of light to dry (brittle) for about 10 days.

\subsection{Making Moringa Powder Dip}

The seeds are blended until smooth so that they form powder. Then dried until there is no water content left. After that the process of making Moringa dye powder can begin. The dried powder is weighed as much as 2-3 grams and then put into a teabag container. Then glued using a hand sealer. Put in each box 25 packs. Ready for consumption.
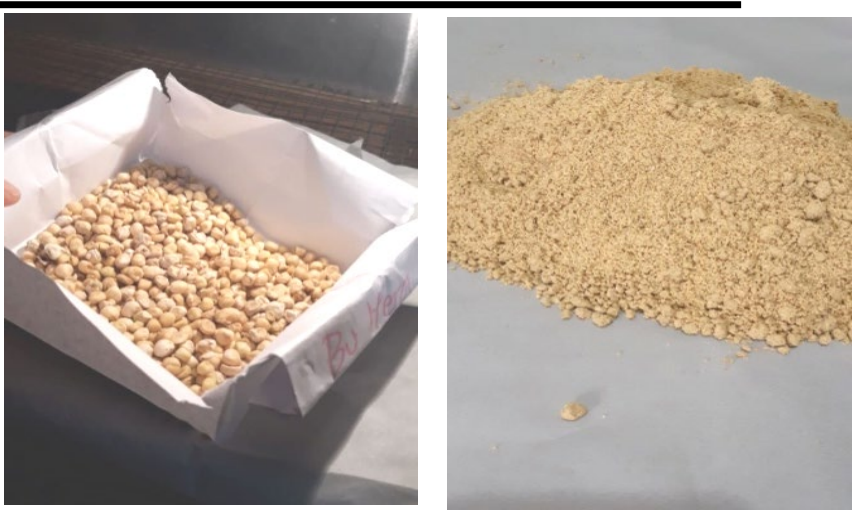

Fig 1. Dry particles and dried moringa powder

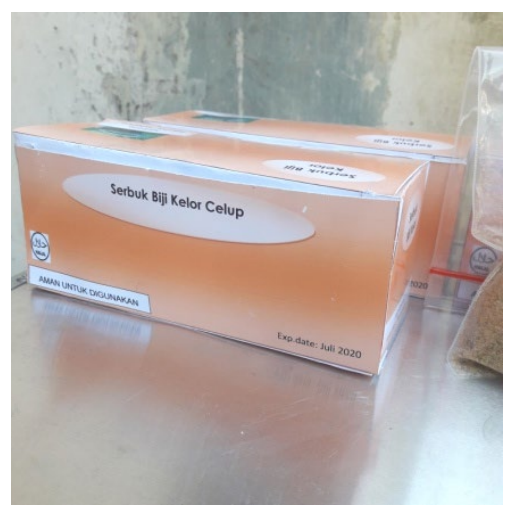

Fig 2. Moringa powder dipped

\subsection{Moringa Powder as Well Water Purifier}

The water of the dug well is drilled as much as 1 gallon $(20 \mathrm{~L})$ and then measured by its $\mathrm{pH}$. Then 1 pack of moringa powder is put into the well water for 1 gallon for 30 minutes. Then compare it with the eyes with gallons of water from the factory color and clarity. In comparison, the $\mathrm{pH}$ of the two types of water can also be measured.

\subsection{Marketing of Moringa Powder}

Marketing of Moringa dye powder can be done in two way, there is door to door and online system. The first way is known as picking up the ball by going to the local people who do need moringa powder to purify the well water. This method is quite effective and low in marketing costs because the marketing area is only limited to the area of residence and does not require transportation costs. 
While marketing the second way is through electronic media with an online shop system. Products can be marketed in a very wide area by making advertisements on social media. For marketing costs, it requires internet quota fees and freight transportation.

\section{RESULTS AND DISCUSSION}

This dedication activity aims to help residents of Padang Bulan Selayang 2 village to be able to make their own Moringa seed powder with tools and ingredients that have been available. Moringa powder is used as a water purifier for consumption of daily needs.

Some of the factors that cause less effective moringa seeds in killing bacteria are moringa seeds which are done maunal, the results are not too smooth, so special defeats need to be done for Moringa seeds so the results are smoother. If the powder of Moringa seeds is finer, it will easily dissolve in water (Latif, 2014).

Moringa is useful because it has antimicrobial properties, especially against bacteria. These antimicrobial properties are capable of destroying bacteria, so that even though there are bacteria in the water Escherichia coli (one of the bacteria contained in drinking water) it can be reduced or killed (Tilong, 2012). Processing of water with Moringa seeds is very effective because water is colorless, tasteless and does not smell like the picture below:

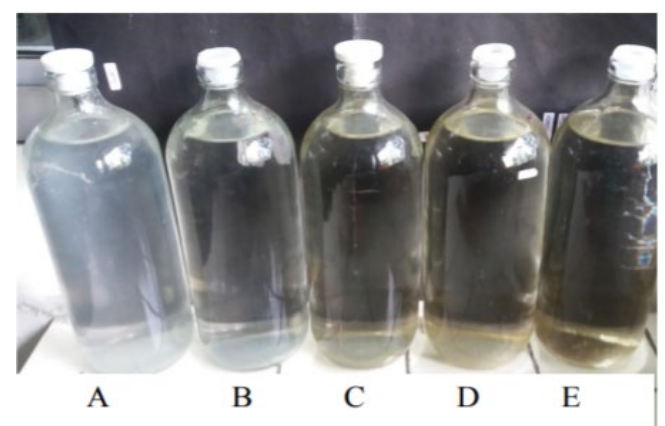

Fig 3. Well water dug before and after addition of Moringa seed powder
Description:
$\mathrm{A}=0.01 \%$;
$\mathrm{B}=0.005 \%$;
$\mathrm{C}=0.0025 \%$;
$\mathrm{D}=0.00125 \%$;
$\mathrm{E}=0$

Moringa seed powder was effective in killing Escherichia coli colonies at a concentration of $0.01 \%$. (Rangkuti, YP, 2017).

\section{CONCLUSION}

Effective Moringa seed powder Moringa seed powder is effective in killing Escherichia coli colonies, there is a concentration of $0.01 \%$. By using the dye method so that it is practical for its use and can also be sold in the market to increase people's income.

\section{ACKNOWLEDGMENT}

We would like to thank the Rector of University of Sumatera Utara for funding this project through a Program Pengabdian Tahun 2018 scheme. In addition, our sincere thank also goes to the Community Service Institute of the University of Sumatera Utara for the facilities during the completion of this project.

\section{REFERENCE}

Kharistya. Appropriate technology. http://kharistya.wordpress.com/2006/11/ 09/ technology-appropriate-usepurification-water-with-seed-Moringamoringa-oleifera. Accessed on November 13, 2007.

Khasanah, U. 2008. Effectiveness of Lamk Moringa oleifera Moringa Seed as a Phosphate Coagulant in Hospital Liquid Waste. Case Study at Dr. RSU Saiful Anwar Malang. Essay. Chemistry Department, Faculty of Science and Technology, State University of Malang. Page 11,13,46. 
Nurul.et.al. Marketing And Utilization Of Moringa Seeds (Moringa Oleifera Lamk) As Well Water Purifiers In Padang Bulan Selayang District 2.

Munfiah, S, Nurjazuli, Setiani, O.https://media.neliti.com/media/public ations/4800-ID-kualitas-fisik-dankimia-air-sumur-gali-dan-sumur-bor-diwupaten-kerja-puskesmas.pdf. Indonesian Environmental Health Journal Vol. 12 No. October 2nd, 2013.

Rangkuti, Y.P. 2017. Analysis of Escherichia coli Before and After Addition of Moringa Seeds (Moringa oleifera Lam) to Well Water Dig. University of
Northern Sumatra.

Tilong, A. D. 2012. It turns out Kelor Conqueror Diabetes. DIVA Press

(Member of IKAPI). Yogyakarta. Page 10-15, 33-35.

Umar, M.R and Liong, S. 2014. Effectiveness of Oleifera Lam Moringa Moringa Seed Powder in Lowering Cadmium Levels in Water. Journal of Nature and Environment, Biology Department, FMIPA Hasanuddin University. 